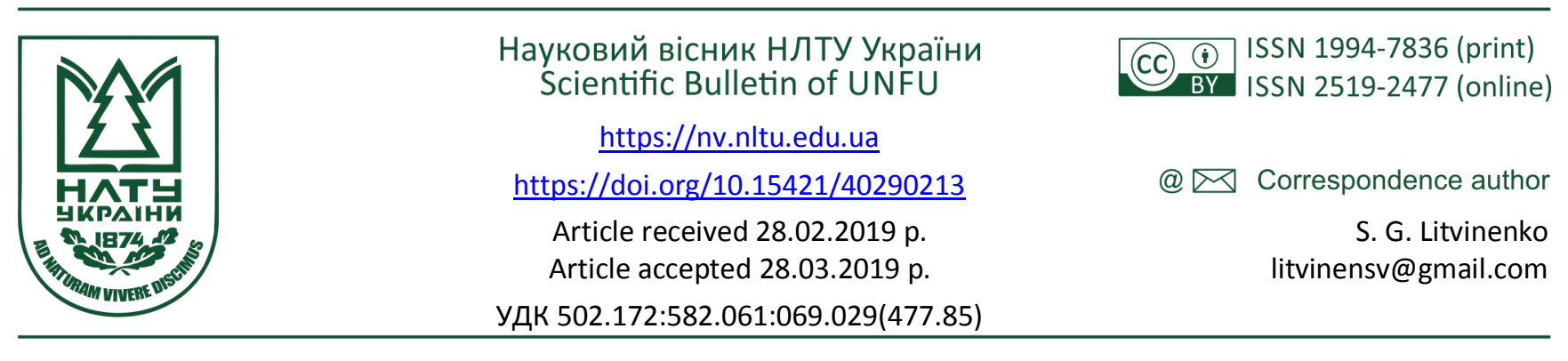

С. Г. Літвіненко ${ }^{1}$, М. І. Виклюк

${ }^{1}$ Чернівецький національний університет ім. Юрія Федьковича, м. Чернівиі, Украйна ${ }^{2}$ Ботанічний сад Чернівецького національного університету ім. Юрія Федьковича, м. Чернівиі, Украйна

\title{
ДЕНДРОСОЗОФІТИ БОТАНІЧНОГО САДУ ЧЕРНІВЕЦЬКОГО НАЦІОНАЛЬНОГО УНІВЕРСИТЕТУ ІМЕНІ ЮРІЯ ФЕДЬКОВИЧА
}

Встановлено, що у ботанічному саду Чернівецького національного університету в умовах відкритого грунту зростає 211 видів дендросозофітів із 87 родів, 37 родин, 2 відділів. Серед них із відділу Pinophyta провідними за кількістю видів $є$ роди Pinus L., Abies Mill., Picea Dietr., Juniperus L., a iз Magnoliophyta - Rhododendron L., Magnolia L., Acer L., Quercus L., Malus Mill. У Червоному списку МСОП досліджувані види віднесено до 6 категорій раритетності; з них переважає група таксонів з низьким рівнем ризику зникнення (82,9\% видів). До групи під загрозою зникнення (категорії CR, EN, VU) входить 20 видів. До Європейського Червоного списку внесено 9 із досліджуваних видів. 7 видів внесено до Червоної книги України (2009), a Syringa josikaea - також до Додатку I Бернської конвенції. Показано, що в умовах ботанічного саду Чернівецького національного університету 174 із досліджуваних дендросозофітів формують життєздатне насіння, а у 42 із них відзначено самосів. Виявлено, що 192 види повністю пристосувалися до умов культивування і мають найвищий ступінь акліматизації (I). Виділено види, які в Чернівецькій області стали інвазійними (Robinia pseudoacacia L., Acer negundo L., Quercus rubra L.), а також типові для Буковини види; всі вони мають категорію LC у Червоному списку МСOП. Успішна акліматизація та здатність до насіннєвого розмноження більшості видів свідчать про те, що колекційні фонди ботанічного саду Чернівецького національного університету є потенціалом для ефективного збереження дендросозофітів ex-situ.

Ключові слова: види деревних рослин; ботанічний сад; Чернівецька область; Червоний список МСОП; Червона книга України; ступінь акліматизації; насіннєве розмноження.

Вступ. Збереження генетичного фіторізноманіття в умовах ex-situ - одне з ключових завдань ботанічних caдів і дендропарків. На сучасному етапі розвитку цих природоохоронних територій збір інформації про раритетні види деревних рослин, зокрема про видовий склад, таксаційні параметри та показники життездатності, $є$ важливим для планування заходів з їхнього подальшого збереження. Подібну інформацію наведено у численних публікаціях. Так, В. А. Медведєв та О. О. Ільєнко (Medvedev \& Iljenko, 2015) наводять видовий склад дендросозоекзотів відділу Pinophyta, культивованих в умовах дендропарку "Тростянець" НАН України, та результати оцінювання життєздатності цих видів. Таксономічний склад і аутфітосозологічну характеристику раритетних дендроекзотів колекцій відкритого i закритого грунту ботанічних садів, дендропарків і парків-пам'яток садово-паркового мистецтва Лісостепу України проаналізували Я. М. Дяченко (Dyachenko, 2011) i Н. П. Степаненко (Stepanenko, 2011). Аналіз видового складу та аутфітосозологічну оцінку дендроекзотів $e x$ situ Степу України здійснили А. С. Власенко та С. Ю. Попович (Vlasenko \& Popovych, 2016). Таксономічний склад раритетних дендроекзотів ботанічного саду Хмельницького національного університету дослідила Л. П. Ка- зімірова (Kazimirova, 2017). Структурний та аутфітосозологічний аналіз, оцінку декоративності та успішності інтродукції раритетних дендроекзотів ботанічних садів і дендропарків Львівської, Тернопільської і Хмельницької областей здійснив Л. В. Міськевич (Miskevych, 2016, 2018). Раритетну дендрофлору парків Вінницької області дослідила Н. О. Сиплива (Sipliva, 2009). Таксономічний склад і декоративність раритетної дендроекзофлори парків-пам'яток садово-паркового мистецтва Житомирської, Чернігівської, Волинської, Рівненської, Сумської та Київської областей проаналізувала А. М. Савоськіна (Savoskina, 2016). Щодо Чернівецької області, у попередній нашій публікації (Litvinenko \& Vykliuk, 2018) наведено видовий склад, деякі таксаційні параметри і адаптаційні показники дендросозоекзотів ботанічного саду Чернівецького національного університету (ЧНУ), які належать лише до відділу Pinophyta. Проте повного переліку дендросозофітів, культивованих у відкритому грунті ботанічного саду ЧНУ, ще не подано.

Тому мета нашої роботи - встановити видовий склад дендросозофітів, які культивуються у ботанічному саду ЧНУ, здійснити їх созологічний аналіз та оцінити ступінь акліматизації за умов культивування.

Об'єкт і методи дослідження. Об'єкт досліджень -

Інформація про авторів:

Літвіненко Світлана Григорівна, канд. біол. наук, доцент, кафедра ботаніки, лісового і садово-паркового господарства. Email: litvinensv@gmail.com

Виклюк Марія Ільківна, провідний фахівець, відділ рослин відкритого ґрунту. Email: litvinensv@gmail.com

Цитування за ДСТУ: Літвіненко С. Г., Виклюк М. І. Дендросозофіти ботанічного саду Чернівецького національного університету імені Юрія Федьковича. Науковий вісник Нлту України. 2019, т. 29, № 2. С. 65-72.

Citation APA: Litvinenko, S. G., \& Vykliuk, M. I. (2019). Rare arboreous plants in the yuriy Fedkovych Chernivtsi national university botanic garden. Scientific Bulletin of UNFU, 29(2), 65-72. https://doi.org/10.15421/40290213

Науковий вісник НЛтУ України, 2019, т. 29, № $2 \quad$ Scientific Bulletin of UNFU, 2019, vol. 29, no 2 
аборигенні та інтродуковані дендросозофіти ботанічного саду Чернівецького національного університету ім. Юрія Федьковича (ЧНУ), які зростають в умовах відкритого грунту. До дендросозофітів віднесено деревні рослини, занесені до офіційних міжнародних "червоних списків", зокрема до Червоного списку МCOП (IUCN 2018), Європейського Червоного списку тварин і рослин, що перебувають під загрозою зникнення у світовому масштабі (Bilz et al., 2011), Додатків Бернської конвенції (Convention, 1979), а також види, які охороняються на державному рівні і відповідно внесено до Червоної книги України (2009) (Popovych \& Varchenko, 2009).

Таксономічне положення представників відділу $P i$ nophyta подано згідно 3 міжнародною класифікацією голонасінних (Kuznetsov et al., 2013), а покритонасінних - за системою APG IV (Chase et al., 2016), яку використано у Червоному списку МСОП.

Для созологічного аналізу використано Червоний список МСОП (IUCN 2018) та "The Red List of Rhododendrons" (Gibbs et al., 2011) для видів роду Rhododendron L., а також Свропейський Червоний список (Bilz et al., 2011) і Червону книгу України (2009). Окрім цього, з'ясовано наявність видів у Додатках Бернської конвенції (Convention, 1979). Ступінь акліматизації деревних рослин до умов культивування визначено за шкалою, запропонованою М. А. Кохно (Kochno \& Kurdjuk, 1994). Зазначено також можливі способи розмноження досліджуваних видів в умовах культивування у ботанічному саду ЧНУ, враховуючи при цьому їхню здатність до формування життездатного насіння саме в наших умовах.

Результати дослідження та їх обговорення. 3'ясовано, що у ботанічному саду ЧНУ в умовах відкритого грунту зростає 211 видів раритетних деревних рослин із 87 родів, 37 родин, 2 відділів. Серед Pinophyta найчисельнішими за кількістю видів родами є Pinus L., Abies Mill., Picea Dietr., Juniperus L., а серед Magnoliophyta Rhododendron L., Acer L., Magnolia L., Quercus L., Malus Mill. (таблиця). Провідними за кількістю видів дендросозофітів виявилися родини Rosaceae (33 види), Pinaceae (24 види), Cupressaceae (20 видів), Ericaceae (15 видів), Betulaceae (13 видів), Magnoliaceae (11 видів), Fabaceae (11 видів), Sapindaceae (10 видів). У ботанічному саду ЧНУ кількість особин досліджуваних видів змінюється; зокрема, найчисельнішими (10 і більше особин) є Juniperus sabina, Taxus baccata, Corylus avellana, Rhododendron ponticum, Buxus sempervirens, Tilia cordata. Проте 43,9\% видів представлені лише однією рослиною кожен.

Таблиця. Характеристика дендросозофітів ботанічного саду Чернівецького національного університету

\begin{tabular}{|c|c|c|c|c|c|c|}
\hline $\begin{array}{l}\text { № } \\
\text { 3/ח }\end{array}$ & Латинська назва таксонів & $\begin{array}{c}\text { Кіль- } \\
\text { кість у } \\
\text { колекції }\end{array}$ & $\begin{array}{c}\text { Рік } \\
\text { надхо- } \\
\text { дження }\end{array}$ & $\begin{array}{c}\text { Природоохоронний ста- } \\
\text { тус: IUCN 2018/Europe- } \\
\text { an Red List/Червона кн-- } \\
\text { га України (2009) }\end{array}$ & \begin{tabular}{|c|} 
Можливі спо- \\
соби розмно- \\
ження в умовах \\
культивування \\
\end{tabular} & $\begin{array}{l}\text { Ступінь ак- } \\
\text { ліматизації } \\
\text { в умовах } \\
\text { Буковини } \\
\end{array}$ \\
\hline 1 & 2 & 3 & 4 & 5 & 6 & 7 \\
\hline \multicolumn{7}{|c|}{ Pinophyta } \\
\hline \multicolumn{7}{|c|}{ Ginkgoaceae L. } \\
\hline 1 & Ginkgo biloba L. ( $\left.\hat{O}^{1}\right)$ & 3 & до 1877 & EN & нас.* & $\mathrm{I}^{\mathrm{T}}$ \\
\hline \multicolumn{7}{|c|}{ Pinaceae Lindl. } \\
\hline 2 & Abies alba Mill. & 3 & 1947 & LC & нас. & I \\
\hline 3 & A. cephalonica Loud. & 1 & до 1877 & LC & нас. & I \\
\hline 4 & A. concolor (Gord.) Lindl. ex Hildebr. & 1 & 1987 & LC & вег. & I \\
\hline 5 & A. fraseri (Pursh) Poir. & 1 & 1987 & EN & нас. & I \\
\hline 6 & A. holophylla Maxim. & 1 & 1982 & NT & вег. & I \\
\hline 7 & A. nordmanniana (Steven) Spach & 1 & до 1877 & $\mathrm{LC}$ & нас. & I \\
\hline 8 & A. numidica de Lannoy ex Carrière & 1 & 1982 & CR & нас. & I \\
\hline 9 & Larix decidua Mill. & 2 & 1910 & LC & нас. & I \\
\hline 10 & Picea abies Karst. & & & LC & нас. & I \\
\hline 11 & P. asperata Mast. & 3 & 1982 & VU & нас. & I \\
\hline 12 & P. glauca (Moench) Voss. & 1 & 1927 & LC & нас. & I \\
\hline 13 & P. koraiensis Nakai & 2 & 1982 & $\mathrm{LC}$ & вег. & $\mathrm{I}^{2}$ \\
\hline 14 & P. koyamae Shirasawa & 3 & 1967 & CR & вег. & I \\
\hline 15 & P. obovata Ledeb. & 2 & 1982 & LC & вег. & I \\
\hline 16 & Pinus cembra L. & 1 & 1975 & LC/-/ЧКУ (вразливий) & вег. & $\mathrm{II}^{2}$ \\
\hline 17 & P. densiflora Siebold \& Zucc. & 1 & 1980 & $\mathrm{LC}$ & нас. & I \\
\hline 18 & P. koraiensis Siebold \& Zucc & 3 & 1989 & LC & вег. & $\mathrm{II}^{2}$ \\
\hline 19 & P. mugo Turra & 1 & 1937 & LC & нас. & I \\
\hline 20 & P. nigra Arn. & 3 & до 1877 & LC & нас. & I \\
\hline 21 & P. strobus L. & 3 & до 1877 & $\mathrm{LC}$ & нас. & I \\
\hline 22 & P. sylvestris L. & 3 & 1937 & LC & нас. & I \\
\hline 23 & P. thunbergii Parl. & 2 & 2007 & LC & вег. & $\mathrm{II}^{2}$ \\
\hline 24 & Pseudotsuga menziesii (Mirb.) Franco & 3 & 1972 & LC & вег. & I \\
\hline 25 & Tsuga canadensis (L.) Carrière & 2 & 2005 & NT & вег. & $\mathrm{I}^{2}$ \\
\hline \multicolumn{7}{|c|}{ Cupressaceae Gray } \\
\hline 26 & Calocedrus decurrens (Torr.) Florin & 2 & 1982 & LC & вег & $\mathrm{II}^{3}$ \\
\hline 27 & Chamaecyparis lawsoniana (A. Murray bis) Parl. & 1 & 1877 & NT & нас. & I \\
\hline 28 & Ch. obtusa (Siebold \& Zucc.) Endl. & 2 & 1998 & NT & нас. & I \\
\hline 29 & Ch. pisifera (Sieb. \& Zucc.) Endl. & 1 & 1907 & LC & нас. & I \\
\hline 30 & Cryptomeria japonica (Thunb. ex L.f.) D. Don & 4 & 1980 & NT & нас., вег. & I \\
\hline 31 & Cunninghamia lanceolata (Lamb.) Hook. & 1 & 1980 & LC & нас., вег. & I \\
\hline 32 & Juniperus chinensis L. & 3 & 1937 & $\mathrm{LC}$ & нас., вег. & I \\
\hline 33 & J. communis L. & 3 & 1997 & LC & нас., вег. & I \\
\hline 34 & J. horizontalis Moench. & 2 & 2002 & LC & вег. & I \\
\hline 35 & J. sabina L. & куртина & 1941 & $\mathrm{LC}$ & вег. & I \\
\hline
\end{tabular}




\begin{tabular}{|c|c|c|c|c|c|c|}
\hline 1 & 2 & 3 & 4 & 5 & 6 & 7 \\
\hline 36 & J. virginiana L. & 1 & 1981 & LC & нас. & I \\
\hline 37 & Metasequoia glyptostroboides $\mathrm{Hu} \&$ W. C. Cheng & $\begin{array}{l}1 \\
1\end{array}$ & $\begin{array}{l}1966 \\
1987\end{array}$ & EN & вег. & $\mathrm{II}^{2,3}$ \\
\hline 38 & Microbiota decussata Kom (ô) & 1 & 1980 & LC & вег. & $\mathrm{I}^{1}$ \\
\hline 39 & Platycladus orientalis (L.) Franco & 2 & 1992 & NT & нас. & I \\
\hline 40 & Sequoiadendron giganteum Lindl. & 1 & 1965 & EN & вег. & $\mathrm{I}^{4}$ \\
\hline 41 & Taxodium distichum (L.) Rich. & 1 & до 1877 & LC & вег. & $\mathrm{I}^{4}$ \\
\hline 42 & Thuja occidentalis L. & 1 & 1907 & LC & нас. & I \\
\hline 43 & Th. plicata Donn ex D. Don & 1 & 1907 & LC & нас. & I \\
\hline 44 & Th. standishii (Gordon) Carrière & 2 & 1984 & NT & нас. & I \\
\hline 45 & $\begin{array}{l}\text { Thujopsis dolabrata (Thunb. ex L. f.) Siebold \& } \\
\text { Zucc. }\end{array}$ & 2 & 1980 & $\mathrm{LC}$ & вег. & $\mathrm{I}$ \\
\hline \multicolumn{7}{|c|}{ Taxaceae Gray } \\
\hline 46 & Taxus baccata L. & 12 & 1907-1982 & LC/-/ЧКУ (вразливий) & нас., вег. & I \\
\hline 47 & T. cuspidata Sieb. et Zucc. & 1 & 1977 & LC & нас. & I \\
\hline 48 & Cephalotaxus fortunei Hook. ( $\left.\mathrm{O}^{\Uparrow}\right)$ & 2 & 1987 & LC & вег. & $\mathrm{I}^{1}$ \\
\hline \multicolumn{7}{|c|}{ Magnoliophyta } \\
\hline \multicolumn{7}{|c|}{ Altingiaceae Lindl., nom. cons. } \\
\hline 49 & Liquidambar formosana Hance & 1 & 1982 & $\mathrm{LC}$ & нас. & I \\
\hline 50 & L. styraciflua L. & 2 & 1937 & $\mathrm{LC}$ & нас. & I \\
\hline \multicolumn{7}{|c|}{ Anacardiaceae R. Br., nom. cons. } \\
\hline 51 & Cotinus coggygria Scop. & 1 & 1957 & $\mathrm{LC}$ & нас. & I \\
\hline 52 & Rhus typhina $\mathrm{L}$ & 2 & 1997 & $\mathrm{LC}$ & нас., вег. & I \\
\hline \multicolumn{7}{|c|}{ Aquifoliaceae Bercht. \& J. Presl, nom. cons. } \\
\hline 53 & Ilex aquifolium $\mathrm{L}$. & $\begin{array}{l}2 \\
3\end{array}$ & $\begin{array}{l}1977 \\
1997\end{array}$ & $\mathrm{LC}$ & нас., вег. & $\mathrm{I}-\mathrm{II}^{5}$ \\
\hline \multicolumn{7}{|c|}{ Araliaceae Juss., nom. cons. } \\
\hline 54 & Aralia elata (Mig) Seem. & 3 & 1957 & LC & нас., вег. & I \\
\hline \multicolumn{7}{|c|}{ Betulaceae Gray, nom. cons. } \\
\hline 55 & Alnus incana (L.) Moench. & 3 & 1957 & LC & нас. & I \\
\hline 56 & Betula alleghaniensis Britt. (B. lutea Michx.) & 1 & 1977 & LC & Hac. & I \\
\hline 57 & B. papyrifera Marsh. & 1 & 1983 & LC & нас. & I \\
\hline 58 & B. pendula Roth & $\begin{array}{l}1 \\
1\end{array}$ & $\begin{array}{l}1930 \\
1932\end{array}$ & LC & нас. & I \\
\hline 59 & B. pubescens Ehrh. & 1 & 1937 & $\mathrm{LC}$ & Hac. & I \\
\hline 60 & B. utilis D. Don & 1 & 1977 & LC & нас. & I \\
\hline 61 & Corylus americana Walt. & 1 & 1971 & $\mathrm{LC}$ & нас. & I \\
\hline 62 & C. avellana $\mathrm{L}$. & $\begin{array}{l}2 \\
8 \\
2 \\
\end{array}$ & $\begin{array}{l}1977 \\
1996 \\
2001 \\
\end{array}$ & $\mathrm{LC}$ & нас. & $\mathrm{I}$ \\
\hline 63 & C. colurna L. & 1 & 1877 & LC & нас. & I \\
\hline 64 & C. heterophylla Fisch. ex Trautv. & 1 & 1997 & $\mathrm{LC}$ & нас. & II \\
\hline 65 & C. maxima Mill. & 1 & 1981 & DD & нас. & I \\
\hline 66 & Ostrya carpinifolia Scop. & 1 & 1967 & $\mathrm{LC}$ & нас. & I \\
\hline 67 & O. virginiana (Mill.) K. Koch & 1 & 1997 & $\mathrm{LC}$ & нас. & I \\
\hline \multicolumn{7}{|c|}{ Bignoniaceae Juss., nom. cons. } \\
\hline 68 & Catalpa bignonioides Walt. & 1 & 1997 & DD & нас. & I \\
\hline 69 & C. speciosa Ward. ex Engelm. & 2 & 1952 & $\mathrm{LC}$ & нас. & I \\
\hline \multicolumn{7}{|c|}{ Buxaceae Dumort., nom. cons. } \\
\hline 70 & Buxus sempervirens L. & 10 & 1907 & LC & вег. & I \\
\hline \multicolumn{7}{|c|}{ Caprifoliaceae Juss., nom. cons. } \\
\hline 71 & Sambucus racemosa L. & 2 & 1967 & $\mathrm{LC}$ & нас. & I \\
\hline 72 & Viburnum lentago L. & 4 & 1947 & LC & нас., вег. & I \\
\hline 73 & Weigela subsessilis (Nakai) L. H. Bailey & 2 & 2007 & LC & нас., вег. & I \\
\hline \multicolumn{7}{|c|}{ Celastraceae R. Br., nom. cons. } \\
\hline 74 & Euonymus atropurpureus Jacq. & 2 & 1995 & $\mathrm{LC}$ & нас. & I \\
\hline 75 & E. europaeus L. & 2 & 1987 & LC & нас. & I \\
\hline 76 & E. latifolius (L.) Mill. & 4 & 1981 & $\mathrm{LC}$ & нас. & I \\
\hline 77 & E. nana Bieb. & 5 & 1937 & -/-/ЧКУ (вразливий) & нас., вег. & I \\
\hline \multicolumn{7}{|c|}{ Cannabaceae Martinov, nom. cons. } \\
\hline 78 & Celtis australis L. & 2 & 1992 & $\mathrm{LC}$ & нас. & II \\
\hline 79 & C. caucasica Hohen ex Planch. & 3 & 1967 & $\mathrm{LC}$ & нас. & I \\
\hline 80 & C. occidentalis $\mathrm{L}$. & $\begin{array}{l}3 \\
2\end{array}$ & $\begin{array}{l}1947 \\
1954\end{array}$ & $\mathrm{LC}$ & нас. & I \\
\hline 81 & C. tetrandra Roxb. & 1 & 1967 & $\mathrm{LC}$ & нас. & I \\
\hline 82 & C. tournefortii Lam. & 1 & 1967 & LC & нас. & I \\
\hline \multicolumn{7}{|c|}{ Cercidiphyllaceae Engl., nom. cons. } \\
\hline 83 & Cercidiphyllum japonicum Siebold \& Zucc. & $\begin{array}{l}1 \\
2 \\
1\end{array}$ & $\begin{array}{l}1967 \\
1917 \\
2013\end{array}$ & NT & нас. & I \\
\hline & Cornaced & $e$ Ber & \& J. Presl & nom. cons. & & \\
\hline 84 & Cornus alternifolia L.f. & 3 & 1987 & $\mathrm{LC}$ & нас. & I \\
\hline 85 & C. darvasica (Pojak.) Pilip & 1 & 1992 & $\mathrm{CR}$ & нас. & I \\
\hline
\end{tabular}




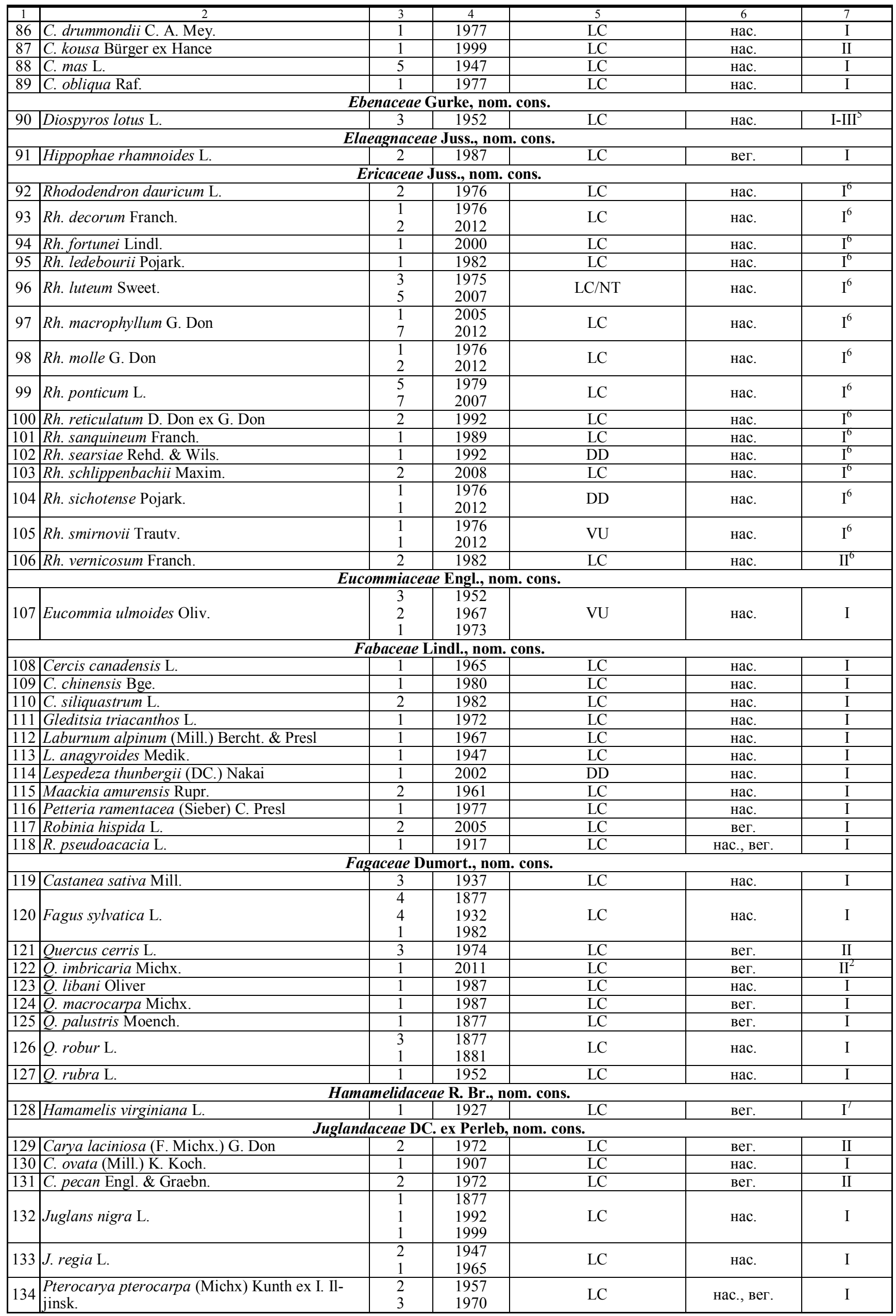




\begin{tabular}{|c|c|c|c|c|c|c|}
\hline 1 & 2 & 3 & 4 & 5 & 6 & 7 \\
\hline \multicolumn{7}{|c|}{ Malvaceae Juss., nom. cons. } \\
\hline 135 & Tilia americana $\mathrm{L}$. & 1 & 1907 & $\mathrm{LC}$ & нас. & I \\
\hline 136 & T. cordata Mill. & $\begin{array}{c}3 \\
1 \\
10\end{array}$ & $\begin{array}{l}1897 \\
1923 \\
1945\end{array}$ & $\mathrm{LC}$ & нас. & I \\
\hline 137 & T. platyphyllos Scop. & 1 & 1907 & LC & нас. & $\mathrm{I}$ \\
\hline \multicolumn{7}{|c|}{ Magnoliaceae Juss., nom. cons. } \\
\hline 138 & Liriodendron tulipifera $\mathrm{L}$. & $\begin{array}{l}2 \\
1\end{array}$ & $\begin{array}{l}1897 \\
2002\end{array}$ & $\mathrm{LC}$ & нас. & I \\
\hline 139 & Magnolia acuminata L. & 1 & 1972 & LC & нас. & I \\
\hline 140 & M. denudata Desr. & $\begin{array}{l}2 \\
1 \\
\end{array}$ & $\begin{array}{l}1987 \\
2008 \\
\end{array}$ & $\mathrm{LC}$ & нас. & I \\
\hline 141 & M. kobus DC. & $\begin{array}{l}2 \\
1 \\
1 \\
\end{array}$ & $\begin{array}{l}1997 \\
2003 \\
2005\end{array}$ & DD & нас. & $\mathrm{I}$ \\
\hline 142 & M. liliflora Desr. & 1 & 1992 & $\mathrm{DD}$ & нас. & I \\
\hline 143 & M. obovata Thunb. & 2 & 1962 & $\mathrm{LC}$ & нас. & I \\
\hline 144 & M. officinalis Rehd. \& Wils. & 1 & 1987 & EN & нас. & I \\
\hline 145 & M. salicifolia Maxim. & 1 & 1972 & $\mathrm{LC}$ & нас. (рідко), вег. & I \\
\hline 146 & M. sieboldii K. Koch & 2 & 2001 & LC & нас. & I \\
\hline 147 & M. stellata Maxim. & 1 & 2002 & EN & нас. & I \\
\hline 148 & M. tripetala $\mathrm{L}$. & 1 & & $\mathrm{LC}$ & нас. & I \\
\hline \multicolumn{7}{|c|}{ Moraceae Gaudich., nom. cons. } \\
\hline 149 & Maclura pomifera (Raf.) C. K. Schneid. (o) & 2 & 1957 & LC & вег. & $\mathrm{II}^{2}$ \\
\hline \multicolumn{7}{|c|}{ Oleaceae Hoffmanns. \& Link, nom. cons. } \\
\hline 150 & Forsythia europaea Degen \& Bald & 3 & 1952 & $\mathrm{LC}$ & вег. & $\mathrm{I}$ \\
\hline 151 & F. ovata Nakai & 3 & 1986 & EN & вег. & I \\
\hline 152 & Fraxinus americana $\mathrm{L}$. & 2 & 1971 & $\mathrm{CR}$ & нас. & $\mathrm{I}$ \\
\hline 153 & F. excelsior L. & $\begin{array}{l}1 \\
2\end{array}$ & $\begin{array}{l}1907 \\
1912\end{array}$ & NT & нас. & I \\
\hline 154 & F. mandshurica Rupr. & 2 & 1971 & LC & нас. & I \\
\hline 155 & F. ornus L. & 2 & 1985 & LC/-/ЧКУ (рідкісний) & вег. & I \\
\hline 156 & F. pensylvanica March. & 1 & 1951 & $\mathrm{CR}$ & нас. & I \\
\hline 157 & Syringa josikaea Jacq. fil. & 1 & 1937 & $\begin{array}{c}\text { EN/EN/ЧКУ (вразли- } \\
\text { вий)/Bern Conv. Annex I }\end{array}$ & нас., вег. & I \\
\hline 158 & S. vulgaris L. & 5 & 1957 & $\mathrm{LC} / \mathrm{LC}$ & нас., вег. & I \\
\hline \multicolumn{7}{|c|}{ Rhamnaceae Juss., nom. cons. } \\
\hline 159 & Frangula alnus Mill. & 2 & 1927 & $\mathrm{LC}$ & нас. & I \\
\hline 160 & Rhamnus cathartica L. & 2 & 1927 & LC & нас. & I \\
\hline 161 & Ziziphus jujuba Mill. & 2 & 2007 & LC & нас. & I \\
\hline \multicolumn{7}{|c|}{ Rosaceae Juss., nom. cons. } \\
\hline 162 & Aflatunia ulmifolia (Franch.) Vassilcz. & 2 & 1997 & LC & нас. & I \\
\hline 163 & Amelanchier alnifolia (Nutt.) Nutt. & 1 & 1977 & LC & нас. & I \\
\hline 164 & Amygdalus ledebouriana Schlecht. & 2 & 1982 & EN & вег., нас. & II \\
\hline 165 & A. nana $\mathrm{L}$ & 3 & 1987 & DD & вег., нас. & II \\
\hline 166 & Crataegus crus-galli L. & 1 & 1997 & $\mathrm{LC}$ & нас. & I \\
\hline 167 & C. douglasii Lindl. & 1 & 1972 & $\mathrm{LC}$ & нас. & I \\
\hline 168 & C. holmesiana Ashe & 2 & 1982 & $\mathrm{LC}$ & нас. & I \\
\hline 169 & C. nigra Waldst. \& Kit. & 1 & 1992 & EN & нас. & I \\
\hline 170 & C. punctata Jacg. & 2 & 1972 & $\mathrm{LC}$ & Hac. & $\mathrm{I}$ \\
\hline 171 & Laurocerasus officinalis Roem. & 1 & 1972 & $\mathrm{LC} / \mathrm{LC}$ & нас., вег. & $\mathrm{I}-\mathrm{II}^{3}$ \\
\hline 172 & Malus baccata (L.) Borkh. & 3 & 1967 & LC & нас. & I \\
\hline 173 & M. fusca (Raf.) C. K. Schneid. & 1 & 2007 & LC & нас. & I \\
\hline 174 & M. hupehensis (Pamp.) Rehd. & 1 & 1982 & $\mathrm{LC}$ & нас. & I \\
\hline 175 & M. niedzwetzkyana Dieck ex Koehne & 1 & 1967 & EN & нас., вег. & I \\
\hline 176 & M. prunifolia (Willd.) Borkh. & 3 & 1967 & DD & нас. & I \\
\hline 177 & M. sikkimensis (Wenz.) Koehne & 1 & 1967 & DD & нас. & I \\
\hline 178 & M. zumi (Matsum) Rehder & 2 & 1987 & DD & нас. & I \\
\hline 179 & Mespilus germanica L. & 2 & 1972 & $\mathrm{LC}$ & нас. & I \\
\hline 180 & Prunus avium (L.) L. & $\begin{array}{l}1 \\
1\end{array}$ & $\begin{array}{l}1927 \\
1967\end{array}$ & $\mathrm{LC}$ & нас. & I \\
\hline 181 & P. cerasifera Ehrh. & 1 & 1962 & DD & вег. & I \\
\hline 182 & P. fruticosa Pall. & 3 & 1962 & $\mathrm{LC} / \mathrm{DD}$ & вег., нас. & I \\
\hline 183 & P. mahaleb L. & 1 & 2013 & $\mathrm{LC} / \mathrm{LC}$ & нас. & I \\
\hline 184 & P. padus L. & 2 & 1967 & $\mathrm{LC} / \mathrm{LC}$ & нас. & I \\
\hline 185 & P. sogdiana Vass. & 1 & 2012 & DD & нас. & I \\
\hline 186 & Pyrus communis L. & 2 & 1957 & $\mathrm{LC} / \mathrm{LC}$ & нас. & I \\
\hline 187 & Rosa acicularis Lindl. & 1 & & LC & нас. & I \\
\hline 188 & R. pendulina L. & 1 & 1972 & $\mathrm{LC}$ & нас. & I \\
\hline 189 & Sorbus aucuparia L. & 3 & 1987 & $\mathrm{LC}$ & нас. & I \\
\hline 190 & S. decora (Sarg.) C. K. Schneid. & 1 & 1987 & LC & нас. & I \\
\hline 191 & S. domestica L. & 1 & 1999 & LC & нас. & I \\
\hline 192 & S. intermedia (Ehrh.) Pers. & 2 & 1967 & $\mathrm{LC}$ & нас. & I \\
\hline
\end{tabular}




\begin{tabular}{|c|c|c|c|c|c|c|}
\hline 1 & 2 & 3 & $\overline{4}$ & 5 & 6 & 7 \\
\hline 193 & S. torminalis Crantz & $\begin{array}{l}1 \\
2 \\
1\end{array}$ & $\begin{array}{l}1897 \\
1967 \\
1992\end{array}$ & LC/-/ЧКУ (неоцінений) & нас. & I \\
\hline 194 & Spiraea cana Waldst. \& Kit. & 2 & 1982 & DD & вег. & $\mathrm{I}$ \\
\hline \multicolumn{7}{|c|}{ Rutaceae Juss., nom. cons. } \\
\hline 195 & Zanthoxylum americanum Mill. ( $\left.\mathrm{O}^{1}\right)$ & 3 & 1982 & LC & вег. & $\mathrm{I}^{\mathrm{T}}$ \\
\hline \multicolumn{7}{|c|}{ Salicaceae Mirb., nom. cons. } \\
\hline 196 & Populus alba $\mathrm{L}$ & 1 & 2012 & $\mathrm{LC}$ & нас. & $\mathrm{I}$ \\
\hline \multicolumn{7}{|c|}{ Sapindaceae Juss., nom. cons. } \\
\hline 197 & Acer barbinerve Maxim. ex Miq. & 2 & 1986 & LC & нас. & $\mathrm{I}$ \\
\hline 198 & A. campestre $\mathrm{L}$. & $\begin{array}{l}2 \\
2 \\
2 \\
1\end{array}$ & $\begin{array}{l}1937 \\
1950 \\
1960 \\
1961\end{array}$ & LC & нас. & I \\
\hline 199 & A. circinatum Pursh. & 1 & 2012 & LC & нас. & I \\
\hline 200 & A. japonicum Thunb. & 1 & 1977 & LC & нас. & $\mathrm{I}$ \\
\hline 201 & A. monspessulanum L. & 1 & 2000 & LC & нас. & I \\
\hline 202 & A. negundo L. & 1 & 1907 & $\mathrm{LC}$ & нас. & $\mathrm{I}$ \\
\hline 203 & A. rubrum L. & 1 & 1997 & $\mathrm{LC}$ & Hac. & $\mathrm{I}$ \\
\hline 204 & A. saccharinum L. & 1 & 1987 & LC & нас. & $\mathrm{I}$ \\
\hline 205 & A. tataricum L. & 2 & 1957 & LC & нас. & I \\
\hline 206 & Aesculus hippocastanum L. & 1 & 1997 & VU & нас. & $\mathrm{I}$ \\
\hline \multicolumn{7}{|c|}{ Staphyleaceae Martinov, nom. cons. } \\
\hline 207 & Staphylea pinnata $\mathrm{L}$. & $\begin{array}{l}1 \\
1 \\
2 \\
\end{array}$ & $\begin{array}{l}1952 \\
1967 \\
1992 \\
\end{array}$ & LC/-/ЧКУ (рідкісний) & нас. & I \\
\hline \multicolumn{7}{|c|}{ Styracaceae DC. \& Spreng., nom. cons. } \\
\hline 208 & Halesia carolina L. & 2 & 1977 & $\mathrm{LC}$ & нас. & I \\
\hline \multicolumn{7}{|c|}{ Ulmaceae Mirb., nom. cons. } \\
\hline 209 & Ulmus laevis Pall. & 1 & 1957 & DD & нас. & $\mathrm{I}$ \\
\hline 210 & U. pumila $\mathrm{L}$. & 1 & 1982 & LC & нас. & $\mathrm{I}$ \\
\hline \multicolumn{7}{|c|}{ Vitaceae Juss., nom. cons. } \\
\hline 211 & Vitis vinifera L. & 2 & 1937 & $\mathrm{LC} / \mathrm{LC}$ & вег., нас. & I \\
\hline
\end{tabular}

Примітки: нас. - розмноження насіннєвим шляхом; вег. - вегетативне розмноження (за відсутності плодоношення або як переважаючий спосіб відтворення); ${ }^{*}$ - насіння отримуємо із жіночих екземплярів за межами ботанічного саду; ${ }^{1-}$ колекційні зразки представлені чоловічими особинами; ${ }^{2}$ - рослини не досягли генеративного віку; ${ }^{3}-$ рослини культивуються в умовах, які не повністю відповідають їхнім екологічним вимогам; ${ }^{4}$ - види представлені єдиним екземпляром і утворюють нежиттєздатне насіння; ${ }^{5}$ - в особливо суворі зими відбувається значне обмерзання рослин, але в наступні роки крона відновлюється; ${ }^{6}$ - успішно розвиваються за умови постійного поливу під час вегетації; ${ }^{7}$ - плодоношення відсутнє у зв'язку 3 цвітінням рослин в осінньо-зимовий період.

Созологічний аналіз показав, що 5 із досліджуваних видів мають категорію CR, 11 - категорію EN, 4 - категорію VU, 9 - категорію NT, 166 - категорію LC i 15 видів - категорію DD у Червоному списку МСОП. До Європейського Червоного списку внесено 9 видів; 3 них лише Syringa josikaea має категорію EN, а решта видів наведені як ті, що перебувають у стані, близькому до загрозливого (NT) - Rhododendron luteum, або ж перебувають під невеликою загрозою зникнення (LC). Окрім цього, 7 видів занесено до Червоної книги України і мають природоохоронний статус "вразливий" (4 види), "рідкісний" (2 види) та "неоцінений" (1 вид). Euonymus nana включений лише до Червоної книги України. Отже, одночасно до 2 созологічних списків внесено 13 видів, 3 яких 2 - представники голонасінних, лише до Червоного списку МСОП - 197 видів, із яких 46 - голонасінні. Серед досліджуваних дендросозофітів варто відзначити Syringa josikaea, який внесено одночасно до 4 созологічних списків (див. таблицю).

Оцінено ступінь акліматизації дендросозофітів до умов культивування. Добрий (II) ступінь акліматизації притаманний 16 видам: Pinus cembra, P. koraiensis, $P$. thunbergii, Quercus imbricaria, Maclura pomifera, Calocedrus decurrens, Metasequoia glyptostroboides, Corylus heterophylla, Celtis australis, Cornus kousa, Quercus cerris, Carya laciniosa, C. pecan, Amygdalus ledebouriana, A. nana, Rhododendron luteum. Майже всі вони, окрім Cornus kousa, Celtis australis та Rhododendron luteum, в умовах ботанічного саду ЧНУ не плодоносять. Ступінь акліматизації трьох видів дендросозофітів змінюється залежно від зимових умов. Зокрема, ступінь акліматизації Diospyros lotus в умовах Саду коливається в межах IIII, оскільки рослини зазвичай плодоносять і формують життєздатне насіння, проте в особливо суворі зими значно обмерзають, і наступного вегетаційного періоду лише відновлюють крону. 3 тієї ж причини ступінь акліматизації Ilex aquifolium і Laurocerasus officinalis змінюється в межах I-II. Решта видів повністю адаптувалися до умов культивування; проте представники роду Rhododendron успішно розвиваються лише за умови постійного поливу під час вегетації. Порівнюючи ступінь акліматизації дендросозофітів різних категорій раритетності, з'ясовано, що лише 2 види, які віднесено до групи категорій під загрозою зникнення (CR, EN, VU) дещо гірше адаптувалися до умов культивування - Metasequoia glyptostroboides i Amygdalus ledebouriana. Проте 18 видів цієї групи пристосувалися до умов культивування повністю.

Треба зазначити, що серед досліджуваних дендросозофітів є інвазійні види (Robinia pseudoacacia, Acer negundo, Quercus rubra), ступінь акліматизації яких також оцінено як найвищий (I), а також види, типові для Чернівецької області - Abies alba, Picea abies, Betula pendula, Alnus incana, Corylus avellana, Sambucus racemosa, Euonymus europaeus, Cornus mas, Fagus sylvatica, Quercus robur, Tilia cordata, T. platyphylos, Fraxinus excelsior, Frangula alnus, 
Sorbus aucuparia, Populus alba, Acer campestre, Prunus avium, Pyrus communis, Ulmus laevis (Horokhova \& Solodkova, 1970). Созологічний статус таких видів у Червоному списку МСОП оцінено категорією LC.

Здатність до насіннєвого розмноження в умовах культури є важливим критерієм успішності збереження виду ex-situ. В умовах ботанічного саду ЧНУ із досліджуваних дендросозофітів 174 види формують життєздатне насіння, а отже, можуть розмножуватися насіннєвим шляхом. У цих же умовах у 42 із них спостережено самосів: Abies cephalonica, Platycladus orientalis, Thuja occidentalis, Th. plicata, Taxus baccata, Buxus sempervirens, Cercidiphyllum japonicum, Eucommia ulmoides, Cercis siliquastrum, Lespedeza thunbergii, Juglans nigra, J. regia, Liriodendron tulipifera, Magnolia kobus, M. sieboldii, Malus niedzwetzkyana, Aesculus hippocastanum, Catalpa bignonioides, C. speciosa, Acer saccharinum, Ulmus laevis тощо. Проте 36 видів дендросозофітів в умовах ботанічного саду ЧНУ не формують насіння або ж не плодоносять. 3 них не досягли генеративного віку Abies concolor, A. holophylla, Picea koraiensis, Pinus cembra, P. koraiensis, P. thunbergii, Tsuga canadensis, Metasequoia glyptostroboides, Juniperus horizontalis, Quercus imbricaria, Q. macrocarpa. Не формують насіння або плодів унаслідок культивування у невідповідних для них екологічних умовах Picea obovata, P. koyamae, Pseudotsuga menziesii, Calocedrus decurrens, Metasequoia glyptostroboides, Thujopsis dolabrata, Corylus heterophylla, Quercus cerris, Cerasus fruticosa, Spiraea cana, Carya laciniosa, C. pecan (ростуть у затіненні); Q. palustris (рівень зволоженості грунту не відповідає потребам цього виду); Hamamelis virginiana (цвіте в осінньозимовий період). Не формують насіння також чоловічі особини Ginkgo biloba, проте у поряд розташованому Центральному парку культури та відпочинку ім. Т. Г. Шевченка разом із чоловічими ростуть жіночі особини цього виду, які утворюють життєздатне насіння. Формують насіння, яке, проте, не сходить, Taxodium distichum i Sequoiadendron giganteum. В окремі роки, після обмерзання в особливо суворі зими, не плодоносять Ilex aquifolium, Diospyros lotus, Laurocerasus officinalis. Тобто із групи видів, які перебувають під загрозою зникнення і тому потребують особливих заходів щодо збереження (категорії CR, EN, VU), тільки один не здатний до насіннєвого розмноження. Натомість 19 видів зазначених категорій успішно формують життездатне насіння.

Висновки. Із 211 видів дендросозофітів, культивованих у ботанічному саду ЧНУ в умовах відкритого грунту, до таксонів з низьким рівнем ризику зникнення (категорії NT, LC) віднесено 82,9 \%. Під загрозою зникнення (категорії CR, EN, VU) перебуває 20 видів $(9,5 \%)$, які й потребують особливих заходів щодо їхного збереження та відтворення. 93,4 \% видів дендросозофітів внесено лише до Червоного списку МСОП; 13 видів - одночасно до двох "червоних списків", a Syringa josikaea - одночасно до трьох "червоних" списків і Додатку I Бернської конвенції. Успішний розвиток досліджуваних дендросозофітів за умов культивування, а також здатність 82,5 \% видів до насіннєвого розмноження $є$ свідченням того, що колекційні фонди ботанічного саду Чернівецького національного університету є потенціалом для ефективного збереження дендросозофітів ex-situ.

\section{Перелік використаних джерел}

Bilz, M., Kell, S. P., Maxted, N., \& Lansdown, R. V. (2011). European Red List of Vascular Plants. Luxembourg: Publications Office of the European Union. Retrieved from: https://www.iucn.org/content/ european-red-list-vascular-plants-1 File RL-4-016.pdf

Chase, M. W., Christenhusz, M. J. M., Fay, M. F., Byng, J. W., Judd, W. S., Soltis, D. E., Mabberley, D. J., Sennikov, A. N., Soltis, P. S., \& Stevens, P. F. (2016). The Angiosperm Phylogeny Group. An update of the Angiosperm Phylogeny Group classification for the orders and families of flowering plants: APG IV. Botanical Journal of the Linnean Society, 181(1), 1-20. https://doi.org/10.1111/boj.12385

Convention. (1979). Convention on the Conservation of European Wildlife and Natural Habitats. Bern. Retrieved from: http://conventions.coe.int/treaty/en/Treaties/Html/104.htm

Didukh, Ya. P. (Ed.). (2009). Red Data Book of Ukraine. Vegetable kingdom. Kyiv: Globalkonsalting, 912 p. [In Ukrainian].

Dyachenko, Ya. M. (2011). Rare alien trees in man-maid protected objects of the Forest-steppe zone of Ukraine: representativeness and outphytosozological checklist. Chornomorsk. botanical journal, 7(2), 132-143. [In Ukrainian].

Gibbs, D., Chamberlain, D., \& Argent, G. (2011). The Red List of Rhododendrons. Retrieved from: https://portals.iucn.org/library/ sites/library/files/documents/RL-2011-002.pdf

Horokhova, Z. N., \& Solodkova, T. I. (1970). Forests of Soviet Bukovina. Lviv: Edition of L'viv University, 213 p. [In Ukrainian].

IUCN 2018. The IUCN Red List of Threatened Species. Version 20182. http://www.iucnredlist.org. Downloaded on 14 November 2018.

Kazimirova, L. P. (2017). Rare dendroflora of the botanical garden of Khmelnytskyi national university. Forestry and gardening, 11. Retrieved from: http://nbuv.gov.ua/UJRN/licgoc_2017_11_8. [In Ukrainian].

Kohno, N. A., \& Kurdiuk, O. M. (1994). Teoreticheskie osnovy i opyt introdukcii rastenij $v$ Ukraine. Kyiv: Nauk. dumka. [In Russian].

Kuznetsov, S. I., Kurdiuk, O. M., Maevsky, K. V., \& Zhila, A. I. (2013). The taxonomic compound and the systematic of Gymnosperms (Pinophyta) of the dendroflora of Ukraine on the basis of their modern classification. Plant introduction, 3, 3-11. [In Ukrainian].

Litvinenko, S. G., \& Vykliuk, M. I. (2018). Species composition and state of rare dendroexotic plants of Pinophyta in Yuriy Fedkovych Chernivtsi National University Botanical Garden. Scientific Bulletin of UNFU, 28(2), 54-58. https://doi.org/10.15421/40280209. [In Ukrainian].

Medvedev, V. A., \& Iljenko, O. O. (2015). Rarity dendroecsotic plants of Pinophyta in the State Dendrological Park Trostjanets of the NAS of Ukraine. Plant introduction, 3, 78-93. [In Ukrainian].

Miskevych, L. V. (2018). Rare exotic dendrosozoflora ex situ of broadleaf forests zone of Ukraine (analysis of structure, representativeness of cultivation, phytocoenodesign). Abstract of Candidate Dissertation for Biology Sciences (06.03.01 - Forest plantation and Phytomelioration). Kyiv, 24 p. [In Ukrainian].

Miskevytch, L. V. (2016). Rare species of arboreal plants in Kremenets Botanical Garden. Scientific Bulletin of UNFU, 26(5), 98-101. https://doi.org/10.15421/40260514. [In Ukrainian].

Popovych, S. Yu., \& Varchenko, N. M. (2009). Metodology of integral outphytosozological evaluation of rare dendroexotic plants. Plant introduction, 4, 11-17. [In Ukrainian].

Savoskina, A. (2016). Evaluation of decorativeness of dendrosozoekzots of the Ukrainian Polissya. Nauk. visnyk Skhidnoievropeisk. Nat. Univers. Biol. Sciences, 12, 19-23. Retrieved from: http://nbuv.gov.ua/UJRN/Nvvnu_2016_12_5. [In Ukrainian].

Sipliva, N. O. (2009). The structural analysis of rare wood flora of parks in Vinnitsa region. Scientific Bulletin of UNFU, 19(5), 39-42. Retrieved from: http://nltu.edu.ua/nv/Archive/2009/19 5/ index19 5.htm. [In Ukrainian].

Stepanenko, N. P. (2011). Analysis of representationess of protected exotic dendrosozoflora ex situ of ForestSteppe of Ukraine. Plant introduction, 1, 19-24. [In Ukrainian].

Vlasenko, A. S., \& Popovych, S. Yu. (2016). Rare exotic arboreal plants of the Steppe of Ukraine. Kyiv: Komprint, 140 p. [In Ukrainian]. 
${ }^{1}$ Yuriy Fedkovych Chernivtsi National University, Chernivtsi, Ukraine ${ }^{2}$ Botanical Garden of Yuriy Fedkovych Chernivtsi National University, Chernivtsi, Ukraine

\section{RARE ARBOREOUS PLANTS IN THE YURIY FEDKOVYCH CHERNIVTSI NATIONAL UNIVERSITY BOTANIC GARDEN}

Collection of information about specific composition, distribution and state of cultivated rare arboreous plants is an important step in creation of conservation measures for these species ex-situ condition. But such information for Chernivtsi region outlined only partially. So, the purpose of our research was to analyze specific composition, their conservation status due to The IUCN Red List of Threatened Species and to evaluate the acclimatization degree of rare aboriginal and introduced arboreous plants cultivated in the Chernivtsi National University Botanic Garden. Conservation status of these species we determined due to The IUCN Red List of Threatened Species, European Red List of Vascular Plants and Red Data Book of Ukraine (2009). Estimation of acclimatization degree, accordingly to M. A. Kochno scale, includes growth, generative development, winter and drought resistance. To the beginning of 2019, 211 species of arboreous plants are growing in the open ground conditions in the Chernivtsi National University Botanic Garden. They are from 87 genus 37 families 2 orders. All species are recorded to The IUCN Red List of Threatened Species and are distributed by 6 categories: 5 of them - to the category CR, 11 species - to EN, 4 - to VU, 9 - to NT, 166 - to LC and 15 species - to the DD category. In the European Red List of Vascular Plants we found 9 species and in the Red Data Book of Ukraine - 7 species. 192 species adapted to the conditions of cultivation completely, and therefore have a higher degree of acclimatization (I). 16 species adapted to cultivation conditions slightly (degree of acclimatization is II), and the degree of acclimatization of 3 species (Diospyros lotus L., Laurocerasus officinalis Roem., Ilex aquifolium L.) varies depending on winter conditions. 174 species in the Botanic Garden form a viable seed. The rest of the species do not fructify because of their young age (11 species), cultivation under the inappropriate ecological conditions (13 species), flowering in the autumn-winter period (Hamamelis virginiana L.). The dioecious species, which are represented only by the male in the Botanic Garden, do not form seeds too. Non-viable seeds form Taxodium distichum (L.) Rich. and Sequoiadendron giganteum Lindl. Consequently, from a group of threatened species (category CR, EN, VU) does not form seeds only 1 of them. High adaptive parameters and the ability to seed reproduction of the majority of investigated species indicate that the collections of the Chernivtsi National University Botanic Garden have high potential for the effective conservation $e x-s i$ $t u$ of rare arboreous plants.

Keywords: arboreous plants; botanic garden; Chernivtsi region; IUCN Red List; Red Data Book of Ukraine; degree of acclimatization; seed reproduction. 